\title{
Article \\ Optimization of Hydroperoxide Lyase Production for Recombinant Lipoxygenase Pathway Cascade Application
}

\author{
Veronika Kazimírová, Viktória Zezulová, Vladimír Krasňan, Vladimír Štefuca (1) and Martin Rebroš * \\ Faculty of Chemical and Food Technology, Institute of Biotechnology, Slovak University of Technology, \\ Radlinského 9, 81237 Bratislava, Slovakia; veronika.kazimirova@stuba.sk (V.K.); zezulova.vk@gmail.com (V.Z.); \\ vladimir.krasnan@stuba.sk (V.K.); vladimir.stefuca@stuba.sk (V.Š.) \\ * Correspondence: martin.rebros@stuba.sk; Tel.: +421-2-59-325-480
}

check for updates

Citation: Kazimírová, V.; Zezulová, V.; Krasňan, V.; Štefuca, V.; Rebroš, M. Optimization of Hydroperoxide

Lyase Production for Recombinant

Lipoxygenase Pathway Cascade Application. Catalysts 2021, 11, 1201. https://doi.org/10.3390/ catal11101201

Academic Editors: Cinzia Calvio and Carlo F. Morelli

Received: 6 August 2021

Accepted: 28 September 2021

Published: 1 October 2021

Publisher's Note: MDPI stays neutral with regard to jurisdictional claims in published maps and institutional affiliations.

Copyright: (C) 2021 by the authors Licensee MDPI, Basel, Switzerland. This article is an open access article distributed under the terms and conditions of the Creative Commons Attribution (CC BY) license (https:// creativecommons.org/licenses/by/ $4.0 /)$.

\begin{abstract}
Cis-3-hexenal and its more stable isomer, trans-2-hexenal, are highly valued chemicals used in the food and perfume industries. They are produced by the plant lipoxygenase pathway, where two enzymes, lipoxygenase (LOX) and hydroperoxide lyase (HPL), are involved. However, the application of this pathway is limited, especially due to the instability of HPL. This enzyme belongs to the cytochrome P450 enzyme family and needs heme as a prosthetic group. Its synthesis must be effectively performed by a host organism in order to produce an active protein. In this work, Pseudomonas aeruginosa LOX was expressed in Escherichia coli BL21(DE3), and whole cells were used for the synthesis of 13(S)-hydroperoxy-(Z,E,Z)-9,11,15-octadecatrienoic acid (13-HPOT) as a substrate for HPL. Expression of Psidium guajava HPL was carried out by recombinant E. coli JM109(DE3) in autoinduction media, and the influence of the addition of heme precursors $\delta$-ALA and $\mathrm{Fe}^{\mathrm{II}+}$ was studied. Specific activity of whole cells expressing HPL was measured by the direct use of a synthesized 13-HPOT solution (2.94 mM of total hydroperoxides, $75.35 \%$ of 13-HPOT (2.22 mM)) and increased 2.6-fold (from $61.78 \mathrm{U} \cdot \mathrm{mg}^{-1}$ to $159.95 \mathrm{U} \cdot \mathrm{mg}^{-1}$ ) with the addition of $1 \mathrm{mM} \mathrm{Fe} \mathrm{FI}^{\mathrm{II}}$ to the autoinduction media. Productivity and activity were further enhanced by an increase in the expression temperature, and a total of $3.30 \cdot 10^{5} \mathrm{U} \cdot \mathrm{dm}^{-3}$ of culture media was produced in the optimized process.
\end{abstract}

Keywords: hydroperoxide lyase; lipoxygenase; 13(S)-hydroperoxy-(Z,E,Z)-9,11,15-octadecatrienoic acid; cis-3-hexenal; cytochrome P450; heme; Escherichia coli

\section{Introduction}

Green leaf volatiles (GLVs) are highly valuable chemicals that are mainly used in the food and perfume industries. They include the short-chain 6-carbon aldehyde cis3-hexenal and its more stable isomer, trans-2-hexenal, among other sensory molecules (C-6 alcohols and their esters) [1,2]. C-6 aldehydes are produced during the oxylipine metabolism of plants-in the lipoxygenase pathway, which consists of two enzymes: lipoxygenase (LOX, linoleate:oxygen oxidoreductase, EC 1.13.11.12) and hydroperoxide lyase (HPL), which is still not registered by the Enzyme Commission (EC). Moreover, other substances produced in this metabolic pathway, such as GLVs, play a role in the signaling and defense of plants [3]. C-6 aldehydes are a subject of study due to their antimicrobial [1,2] and antifungal properties, and they show potential for plant parasite control [4]. Trans-2-hexenal is already used for food conservation-it helps to preserve the color of fruits and vegetables and improves their sensory qualities $[2,4,5]$. The versatile use of oxylipine metabolic products has led to the extensive study of its branches, the lipoxygenase pathway included.

Lipoxygenase belongs to the family of nonheme-containing fatty acid dioxygenases. It mediates the regio- and stereo-specific deoxygenation of poly-unsaturated fatty acids (PUFAs) containing a (1Z, 4Z)-pentadiene system. This includes linoleic acid (C18:2), alpha-linolenic acid (C18:3), and arachidonic acid (C20:4) (the latter is present only in low 
concentrations in plants) [1,6,7]. They are classified as 9 or 13 LOXs according to the products of positional specific oxygenation-depending on the placement of the hydroperoxide moiety on the hydrocarbon backbone [8]. Specificity depends on the space within the active site of LOX and substrate orientation (whether it penetrates the active site with a methyl or carboxyl group) [6] and can be affected by $\mathrm{pH}$ : preference for $\mathrm{C}-9$ is higher at acidic $\mathrm{pH}$ and preference for $\mathrm{C}-13$ at basic $\mathrm{pH}[9]$.

Linolenic and linoleic acids are the primary substrates of LOX in plants. Specificity for position 13 gives 13-hydroperoxides: 13(S)-hydroperoxy-(Z,E,Z)-9,11,15-octadecatrienoic acid (13HPOT) if formed from linolenic acid. This is the substrate needed for 13-HPL to form 12-oxo-(Z)-9-dodecenoic acid and (Z)-3-hexenal (both products undergo isomerization to form 12-oxo-(E)-10-dodecenoic acid and (E)-2-hexenal) (Figure 1). A cascade gives $n$ hexenal if it is started with linoleic acid [1]. In the case of specificity for the 9-position on the hydrocarbon string, 9-HPL produces 8-formyl-octanoic acid and (3Z,6Z)-nonadienal (isomerization to (2E, 6Z)-nonadienal) from linolenic acid and Z-3-nonenal (isomerization to $2 \mathrm{E}-$ nonenal) from linoleic acid [1,2,5,9-12]. It follows that the concentration of these compounds in plants is low due to the further metabolic elimination, and their industrial extraction is too expensive and cannot meet consumer demand [11].

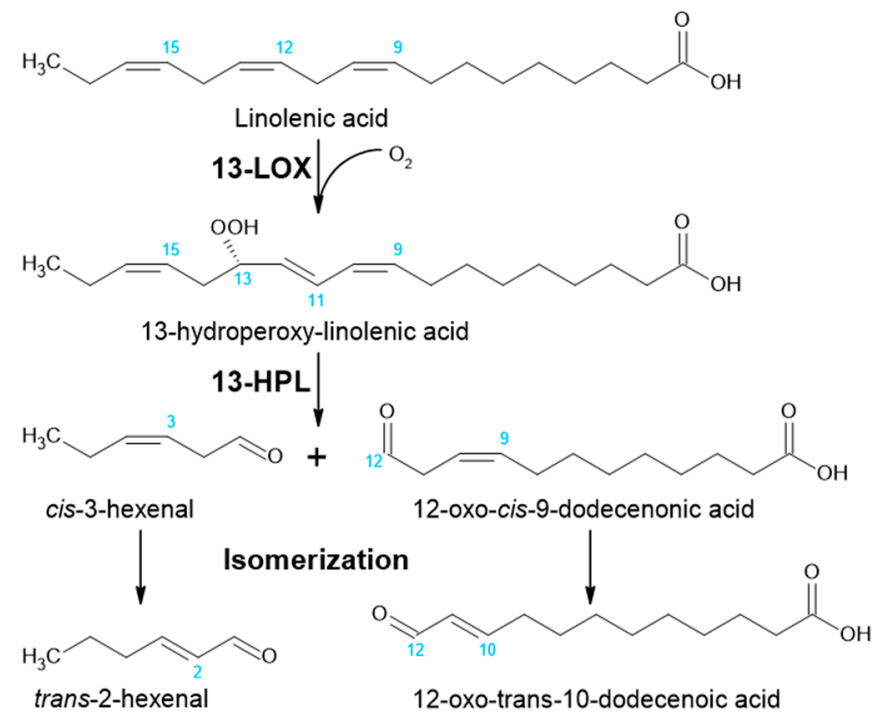

Figure 1. Lipoxygenase pathway with C-13 specific LOX and HPL.

Traditional large-scale aldehyde synthesis by the lipoxygenase pathway includes mixing PUFAs with various plant materials. However, industrial application is limited due to the low stability of HPL $[9,10]$ (irreversible inactivation by the substrate [13] and products [11]), its affinity to membranes [2], and often by the seasonality of biomass supply. Separation of pure products is also difficult because of the complexity of the reaction mixture [14].

Recombinant production of various LOXs has been successfully accomplished in different hosts (Escherichia coli [15], Pichia pastoris [16], extracellular production in Bacillus subtilis [17] and Trichoderma reesei [7]). Although these are valid strategies, studies have never investigated the form of application of the biocatalyst in the biosynthetic process, and there are no data about the enzyme activity of crude microbial lysates expressing LOX, or even about using whole host cells. Activity of extracellularly produced LOX has been reported, but it decreases rapidly after a few days of storage [7].

The lipoxygenase reaction has been successfully carried out at a relatively large scale using various forms of soybean LOX, soy flour [10], or purified enzyme [11,18,19], even in immobilized form [7]. As pointed out by Villaverde [7], soybean LOX is used almost exclusively for this kind of synthesis. Even though LOXs from other sources have been successfully expressed, they have not been used for the synthesis of hydroperoxides for HPL [7,15]. After hydroperoxide 
synthesis, they can be extracted to obtain high purity $[5,7,10,14,19]$, or the reaction mixture can be used in a cascade manner-it is used as a substrate mixture for HPL after only a simple treatment [11].

Based on sequence homology, HPL belongs to the cytochrome P450 family and to CYP47 enzymes [9]. It needs heme-b (protoporphyrine IX) as a prosthetic group in the active site. This has to be taken into consideration when producing HPL in hosts that do not produce heme in their native metabolism [5,9]. Recombinant production has been successfully accomplished in various standard host microorganisms-Escherichia coli $[5,10]$, Pichia pastoris [20], Yarrowia lipolytica [21]. However, many publications do not address heme synthesis or supplementation and rely only on the basal levels of heme produced. This can be satisfactory for laboratory application for structure studies and characterization of the enzyme but not for industrial needs for large quantities of active enzyme.

When addressing an increase in heme content during cultivation, its reactivity and toxicity to cells must be taken into consideration. Its concentration is also strictly regulated in E. coli, and even though heme biosynthesis has been extensively studied, the regulation of this metabolic pathway is very complicated and only limited information is available [22]. A straightforward method of increasing heme availability would be the addition of free heme directly to the culture media; however, its uptake by E. coli strains is limited by diffusion through the cell membrane because there are no heme transporters. This issue can by addressed by the co-expression of heme transporter genes from G- bacteria $[23,24]$.

E. coli heme biosynthesis takes place in cytosol, and it is produced by the "C5 route". The rate limiting step is believed to be the synthesis of a universal tetrapyrrole precursor, $\delta$-aminolevulic acid ( $\delta$-ALA) [23-25]. Some authors report increased yields of the active form of HPL (and other cytochrome P450 proteins) after the addition of $\delta$-ALA to the media [24,25]; some refute this or simply omit any additives [18,26,27].

In this work, LOX was expressed in E. coli BL21(DE3) in a bioreactor to reach high cell density. Cells were harvested and subsequently used for the synthesis of 13HPOT-a substrate for HPL. HPL was expressed in E. coli JM109(DE3) with heme precursors $\delta$ ALA and $\mathrm{Fe}^{\mathrm{II}+}$ in the autoinduction media, and the whole-cell biocatalyst activity of HPL was determined.

\section{Results}

\subsection{Lipoxygenase}

\subsubsection{High Cell Density Cultivation of E. coli Expressing LOX}

Uniformity of the biocatalyst in both industrial and laboratory applications is a very desirable property. For this reason, establishing a reliable and ideally an automatized process is needed. While LOX is a quite ordinary enzyme, for this purpose, it is usually applied as a soyabean powder with LOX content or as a commercial soyabean native enzyme $[10,14,18,19]$. The reliable recombinant production with high cell density cultivation for this process was therefore adapted from Petrovičová et al. [28]. A semi-defined glycerol-based medium and a fed-batch strategy with temperature reduction $\left(18^{\circ} \mathrm{C}\right)$ before the induction (0.5 mM IPTG) were applied (Figure 2).

Growth of biomass was indicated by increased oxygen uptake for substrate consumption and was compensated by the automatic adjustment of agitation. Cooling of the cultivation media prior to induction with IPTG begun when culture reached an optical density of approximately 50. A sudden spike in dissolved oxygen in the 22nd hour of cultivation indicated the depletion of glycerol and was therefore used as a signal for feeding. The final concentration of biomass was $35.6 \mathrm{~g} \cdot \mathrm{dm}^{-3}$, which is comparable to the previously reported protocol for ketoreductase production $\left(38.7 \mathrm{~g} \cdot \mathrm{dm}^{-3}\right.$ for induction at $\left.30{ }^{\circ} \mathrm{C}\right)$, even though the applied temperature was lower $\left(18^{\circ} \mathrm{C}\right)$ [28]. 


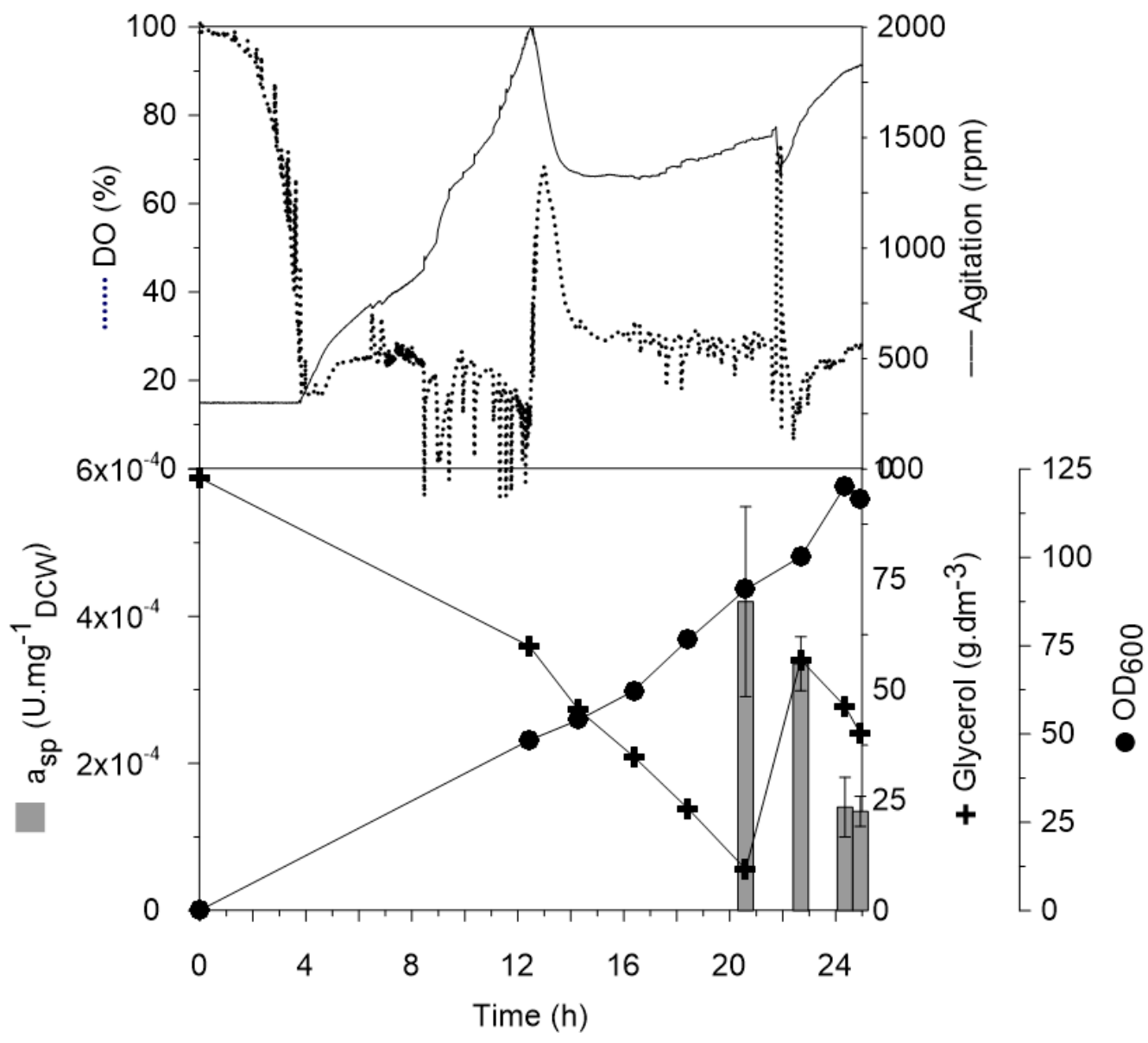

Figure 2. Fed-batch cultivation of E. coli BL21(DE3) expressing LOX. DO-dissolved oxygen (\%), OD $600-$ optical density of culture determined at $600 \mathrm{~nm}$; $\mathrm{a}_{\mathrm{sp}}$-specific activity of E. coli whole cells expressing LOX.

\subsubsection{Synthesis of 13-HPOT}

As mentioned before, soybean powder LOX is almost exclusively used for this kind of synthesis [7]. Pseudomonas aeruginosa LOX in purified form was used for dye decolorization and had standard activity towards linoleic acid [15]. Use of both lipoxygenase pathway enzymes (LOX for production of 13-HPOT and HPL for cis-3-hexenal synthesis) in recombinant form is reported here for the first time. The main goal was to produce a stable, easy to handle, whole-cell biocatalyst and to produce stable 13-HPOT that can be stored for a long time period. A key parameter for the optimization of 13-HPOT was the concentration of aldehydes produced in the further step by the standard HPL reaction (Section 3.7) with reference biomass $\left(37-20^{\circ} \mathrm{C}\right.$, no additives) (Section 3.6).

The biosynthesis of 13-HPOT, a substrate for HPL, was adapted from Vick [29]. The original procedure was performed with partially purified soybean LOX in borate buffer, $\mathrm{pH}=8.9$, and was started by the addition of the substrate solution. The mixture was stirred and pure oxygen was bubbled through it. The course of the reaction was not monitored, but the author stated that it proceeded for "at least $20 \mathrm{~min}^{\prime}$. In this work, the reaction was carried out in a bioreactor to maintain the desirable controlled oxygen supply and its monitoring.

The application of a recombinant, whole-cell biocatalyst for 13-HPOT production was one of the primary goals. Except for the obvious economic advantages of using whole cells over purified enzyme, another useful advantage is that the enzymes produced remain in a protected environment under harsh reaction conditions [30]. Addition of the nonionic detergent Tween 20 has been utilized in the LOX reaction before $[7,15]$, so this step was adapted and used here (30 min permeabilization). Concentrations of synthesized 
hydroperoxides were not different (permeabilization- $\mathrm{P}+$ versus $\mathrm{P}-$ ). However, the solution produced in the P- system contained higher concentrations of C-6 aldehydes, which suggests the partial spontaneous decomposition of hydroperoxides. In addition, E. coli fatty acids released from membranes by Tween 20 can also serve as substrates for LOX. Therefore, LOX activity was monitored by oxygen consumption and the reaction was considered completed when an increase in oxygen was observed. The hydroperoxide solution produced by permeabilized cells appeared to be more suitable according to the amount of C-6 aldehydes produced by the subsequent HPL reaction (data not shown). This can be attributed to the increased stability of HPL in the presence of partially lysed LOX tcells.

During the biotransformation, the rapid decrease in dissolved oxygen indicated the beginning of the reaction (at the addition of substrate solution) (Figure 3).

Interestingly, massive foam formation occurred during the biotransformation. There are no comments about this phenomenon in previous reports, but low media/vessel volume ratios were reported (25-29\%, $v / v$ [31]). Due to the utilization of oxygen as a co-substrate for hydroperoxide formation, air was supplied by a sparger, and proper stirring must be secured. Due to the gas solubility, a temperature as low as $4{ }^{\circ} \mathrm{C}$ was maintained during the biotransformation.

For the determination of HPL activity, a hydroperoxide solution synthesized from $6 \mathrm{mM}$ linolenic acid with permeabilization (Figure 3, solid line) was used. The total concentration of hydroperoxides produced was $2.94 \mathrm{mM}$ with $75.35 \%$ of $13-\mathrm{HPOT}(2.22 \mathrm{mM})$. Problems with iodometric titration occurred with solutions with a higher linolenic acid concentration and longer permeabilization periods-it was not possible to precisely determine the endpoint of the titration. This was presumably caused by the excess of intracellular content that leaked into the reaction mixture and caused interference. If the exact determination of the amount of hydroperoxides synthesized is needed, the best method would be the extraction of the reaction mixture and analysis of the product in pure form [32]. However, to subsequently produce higher concentrations of C-6 aldehydes by HPL and to implement this process at an industrial scale, higher concentrations of linolenic acid should be used.

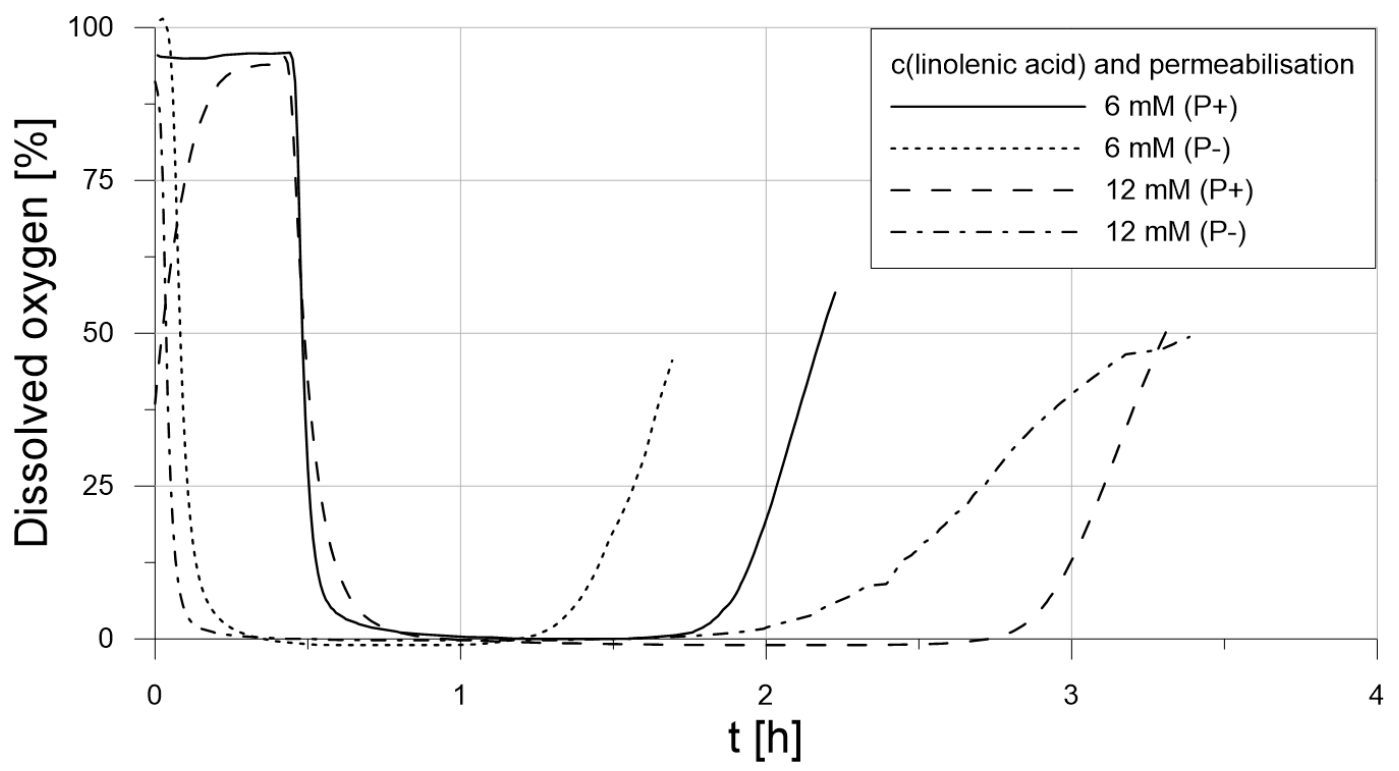

Figure 3. Oxygen monitoring during the synthesis of hydroperoxides by E. coli BL21(DE3) expressing LOX (P+ with permeabilization, P- without permeabilization (see Section 3.5)). 


\subsection{Hydroperoxide Lyase}

The first step for successful recombinant production was the choice of the host strain of the applied microorganism. In the context of the production of active HPL, heme metabolism of the host strain was taken into consideration, since, in this biotransformation, it is essential for the proper biocatalytic function of HPL. Specific activity of E. coli cells (defined in Section 3.7) produced in different conditions was evaluated for the determination of optimal cultivation conditions.

\section{Recombinant Production of HPL}

As reported before, heme metabolism of $E$. coli usually lags behind the rapid recombinant protein synthesis [24]. Only a small fraction of protein is associated with heme (e.g., 15\% for guava HPL-MBP expressed in E. coli MC1061 and vector pMAL-2cX [10]). Attempts to enhance the expression of functional recombinant hemo-proteins include slowing down protein production (e.g., lowering the temperature $[5,10,24,25])$ and adding heme or its precursor $\delta$-ALA into culture media [23,25]. However, some data show that, under proper growth conditions, some $E$. coli strains can produce enough heme without any additional precursors. When the correct concentration of lactose is used in the autoinduction medium to induce the expression of P450 enzyme, the yield increases when compared to induction with the rapid IPTG induction process [26]. Induction with lactose has become well established, mostly due to economic aspects-IPTG tends to be the most expensive component of culture media. While the advantages of lactose induction are quite obvious, there are some specific requirements to be met for the successful implementation of this type of induction. The lac repressor used in T7-based vectors is regulated by allolactose, so active $\beta$-galactosidase is needed for induction with lactose. Some $E$. coli strains contain deletions in the $\beta$-galactosidase gene (lacZ $\Delta \mathrm{M} 15)$ and are unable to respond to the lactose. E. coli JM109(DE3) (the strain commonly used for the expression of P450 proteins) with complemented $\beta$-gal deletion was used [26]. E. coli is heterofermentative and metabolizes different carbon sources in a specific order-it metabolizes glucose before lactose (diauxic shift) [33]. Autoinduction is based on the inhibition of alternative sugar intake by glucose (catabolite repression). After all glucose is metabolized, expression of recombinant protein starts automatically by the utilization of lactose $[34,35]$. Another heme-b-containing protein, Crocodylus siamensis hemoglobin, was successfully produced by autoinduction in E. coli BL21(DE3). The authors reported correct folding and proper heme incorporation without the addition of heme or $\delta$-ALA [36]. Autoinduction also depends on the level of dissolved oxygen $[34,35]$, so optimization of the flask cultivation, such as the media/flask volume ratio, shaking speed, or flask shape, needs to be performed [35]. In an attempt to enhance the expression of active HPL, a combination of all the strategies was incorporated in this work: the use of E. coli JM109(DE3), plasmid pET22b (HPL from guava was cloned within the pelB sequence for periplasmatic location and histidine tag), and the application of an autoinduction strategy under optimized aeration.

To study the possibility of further heme production enhancement, a set of cultivations was carried out to study the relationship between the addition of heme precursor, $\delta$-ALA, to the media and the increase in the activity of ferro chelatase by the simple addition of its substrate $\mathrm{Fe}^{\mathrm{II}+}$ (in the form of $\mathrm{FeSO}_{4}$ ) to the culture media. Various concentrations of $\delta$-ALA and $\mathrm{Fe}^{\mathrm{II}+}$ were applied, and cells were tested for their catalytic activity (Figure 4).

The results show that the addition of $\delta$-ALA to the culture media had a negative effect on both specific activity and biomass formation. On the contrary, the addition of $1 \mathrm{mM}$ $\mathrm{Fe}^{\mathrm{II}+}$ caused a 2.6-fold increase in specific activity in comparison to the reference biomass (produced at $37-20^{\circ} \mathrm{C}$ with no additives). Cultures with $\mathrm{OD}_{600}$ lower than 0.3 were not tested for their activity. All tested samples exhibited the formation of C-6 aldehydes from the hydroperoxide solution prepared by the recombinant LOX biocatalyst from linoleic acid starting material. To the best of our knowledge, this is the first report of increased HPL (or other cytochrome P450) activity by the addition of $\mathrm{Fe}^{\mathrm{II+}}$. Even though some authors briefly mention the addition of $\mathrm{Fe}^{\mathrm{III}+}(2.5 \mathrm{mM})$ to culture media with no increase in 
HPL activity [25], this concentration was too high, and IPTG induction was used, which reportedly decreases HPL activity [10].

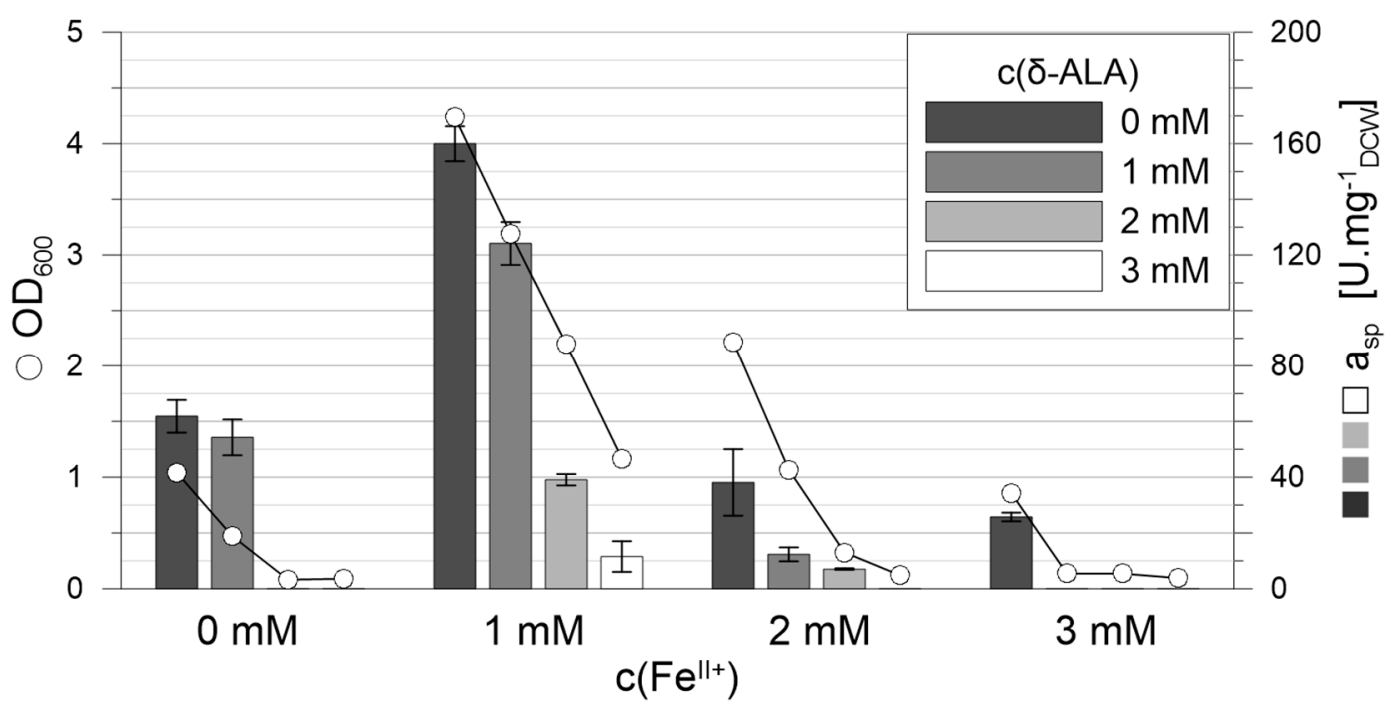

Figure 4. Final $\mathrm{OD}_{600}$ and specific activity of E. coli JM109(DE3) expressing HPL.

Another interesting phenomenon was the increased biomass production during cultivations, which increased specific activity. Since there are no reports of this phenomenon so far, we assume that this was caused by the activation of other iron-dependent enzymes (or iron-containing cofactors), which can play important roles in biological functions [23]. To further exploit this, another cultivation set with combined additions of $1 \mathrm{mM}$ of $\delta$-ALA and $1 \mathrm{mM}$ of $\mathrm{Fe}^{\mathrm{II}+}$ was performed at different temperature regimes: the temperature was not lowered to $20^{\circ} \mathrm{C}$ after $2 \mathrm{~h}$ at $37^{\circ} \mathrm{C}$ but was kept constant at $30{ }^{\circ} \mathrm{C}$ (Figure 5).

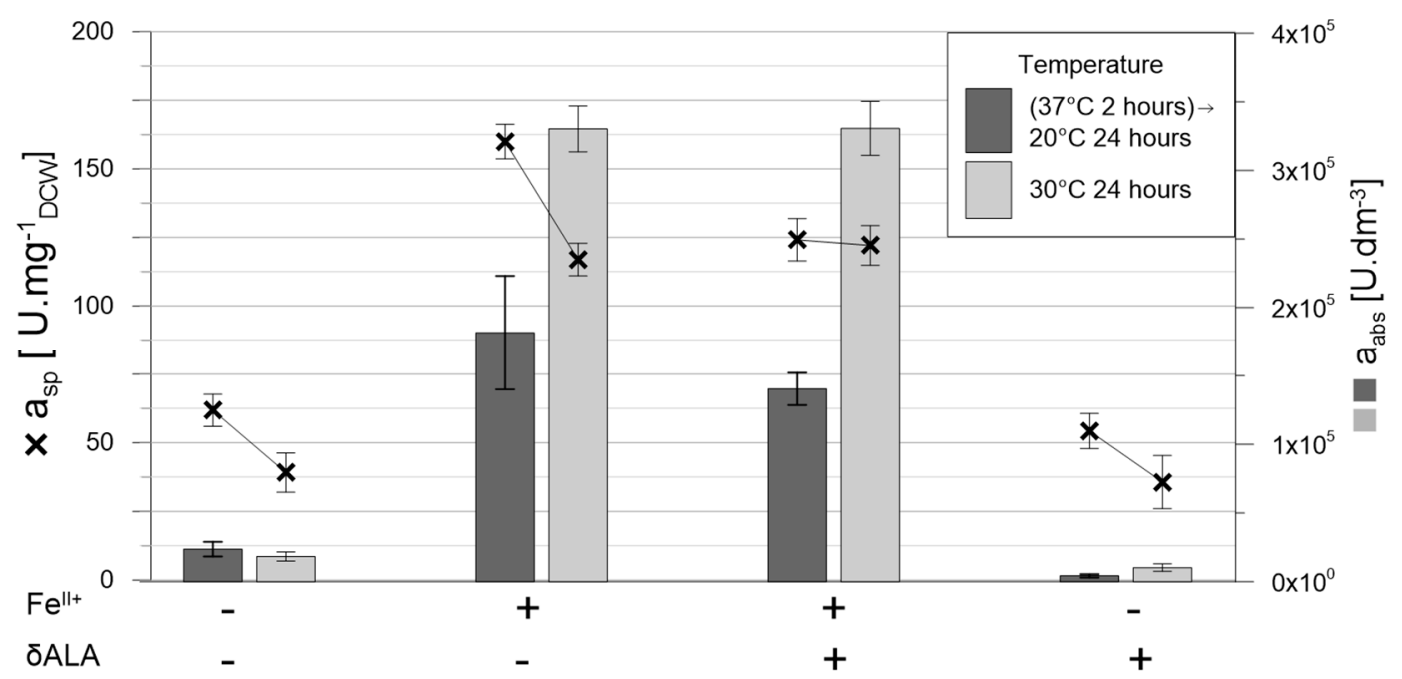

Figure 5. Specific activity of E. coli JM109(DE3) expressing HPL and absolute activity produced per liter of culture media with combination additions of $1 \mathrm{mM}$ of $\delta$-ALA and $1 \mathrm{mM}$ of $\mathrm{Fe}^{\mathrm{II}+}$.

Specific activity of all samples decreased with increasing temperature, but the growth of biomass increased considerably (2-fold increase in the case of addition of $1 \mathrm{mM}$ of $\mathrm{Fe}^{\mathrm{II}+}$ alone). These two phenomena have been taken into account by the calculation of the activity produced per $\mathrm{L}$ of cultivation media. It increased considerably in both cultivations with the addition of $\mathrm{Fe}^{\mathrm{II}+}$ - $\mathrm{a} 1.82$-fold increase with the addition of $1 \mathrm{mM} \mathrm{Fe}^{\mathrm{II+}}$ alone and a 2.35 -fold increase with the addition of $1 \mathrm{mM} \mathrm{Fe}^{\mathrm{II}+}$ and $1 \mathrm{mM}$ of $\delta$-ALA. 
These results are promising not only for laboratory-scale production for enzyme studies but also for the further scaling up of HPL production.

\section{Materials and Methods}

\subsection{Bacterial Strains and Plasmids}

A synthetic gene of lipoxygenase, Pseudomonas aeruginosa (PAO1), was codon-optimized and cloned in NheI and XhoI sites [37] in frame with the N-terminal His tag of pET28b expression vector (resistance to kanamycin) and expressed in Escherichia coli BL21(DE3).

Hydroperoxide lyase from Psidium guajava was ligated into pET22b expression vector (resistance to ampicillin) and expressed in Escherichia coli JM109(DE3).

\subsection{Materials and Media}

Ampicillin and kanamycin were purchased from Gibco ${ }^{\circledR}$ (Life Technologies, Glasgow, UK). Linoleic acid (70\%) was purchased from Sigma-Aldrich (St. Louis, MO, USA). All other chemicals were of analytical grade and commercially available.

Luria-Bertani (LB) medium: tryptone $10 \mathrm{~g} \cdot \mathrm{dm}^{-3}$; yeast extract $5 \mathrm{~g} \cdot \mathrm{dm}^{-3} ; \mathrm{NaCl}$ $10 \mathrm{~g} \cdot \mathrm{dm}^{-3}$; kanamycin $30 \mu \mathrm{g} \cdot \mathrm{cm}^{-3}$ resp. ampicillin $50 \mu \mathrm{g} \cdot \mathrm{cm}^{-3}$. For solid media, $2 \%$ $(w / v)$ agar was added.

M9 medium, final concentrations: glycerol $5 \mathrm{~g} \cdot \mathrm{dm}^{-3} ; \mathrm{MgSO}_{4} 0.493 \mathrm{~g} \cdot \mathrm{dm}^{-3} ; \mathrm{CaCl}_{2}$ $0.011 \mathrm{~g} \cdot \mathrm{dm}^{-3}$; Thiamine- $\mathrm{HCl} 0.001 \mathrm{~g} \cdot \mathrm{dm}^{-3} ; \mathrm{M} 9$ salts: $\mathrm{Na}_{2} \mathrm{PHO}_{4} \cdot 7 \mathrm{H}_{2} \mathrm{O} 64 \mathrm{~g} \cdot \mathrm{dm}^{-3} ; \mathrm{KH}_{2} \mathrm{PO}_{4}$ $150 \mathrm{~g} \cdot \mathrm{dm}^{-3} ; \mathrm{NaCl} 2.5 \mathrm{~g} \cdot \mathrm{dm}^{-3} ; \mathrm{NH}_{4} \mathrm{Cl} 5 \mathrm{~g} \cdot \mathrm{dm}^{-3} ;$ kanamycin $30 \mu \mathrm{g} \cdot \mathrm{cm}^{-3}$. The solutions were sterilized separately $\left(121^{\circ} \mathrm{C}, 120 \mathrm{kPa}, 20 \mathrm{~min}\right)$ and aseptically mixed prior to cultivation. Thiamine- $\mathrm{HCl}, \mathrm{CaCl}_{2}$, and antibiotic solutions were sterilized by filtration on a syringe filter with a polyether sulfone (PES) membrane (Filtropur S; $0.2 \mu \mathrm{m}$; Sarstedt, Germany).

Semi-defined medium for high cell density biomass preparation (expression of LOX): Medium (and feeding medium) was that used by Petrovičová [28] with a different initial concentration of glycerol: glycerol $90 \mathrm{~g} \cdot \mathrm{dm}^{-3}$; tryptone $10 \mathrm{~g} \cdot \mathrm{dm}^{-3} ;\left(\mathrm{NH}_{4}\right)_{2} \mathrm{SO}_{4} 5 \mathrm{~g} \cdot \mathrm{dm}^{-3}$; $\mathrm{NaH}_{2} \mathrm{PO}_{4} \cdot 2 \mathrm{H}_{2} \mathrm{O} 3.64 \mathrm{~g} \cdot \mathrm{dm}^{-3} ; \mathrm{KCl} 3.87 \mathrm{~g} \cdot \mathrm{dm}^{-3}$; citric acid $4 \mathrm{~g} \cdot \mathrm{dm}^{-3} ; \mathrm{MgSO}_{4} \cdot 7 \mathrm{H}_{2} \mathrm{O}$ $2.4 \mathrm{~g} \cdot \mathrm{dm}^{-3}$; trace elements solution $10 \%(v / v)$.

Trace elements solution: citric acid monohydrate $109 \mathrm{~g} \cdot \mathrm{dm}^{-3} ; \mathrm{CaCl}_{2} \cdot 2 \mathrm{H}_{2} \mathrm{O} 3.4 \mathrm{~g} \cdot \mathrm{dm}^{-3}$; $\mathrm{ZnSO}_{4} \cdot 7 \mathrm{H}_{2} \mathrm{O} 2.46 \mathrm{~g} \cdot \mathrm{dm}^{-3} ; \mathrm{MnSO}_{4} \cdot \mathrm{H}_{2} \mathrm{O} 1.52 \mathrm{~g} \cdot \mathrm{dm}^{-3} ; \mathrm{CuSO}_{4} \cdot 5 \mathrm{H}_{2} \mathrm{O} 0.5 \mathrm{~g} \cdot \mathrm{dm}^{-3} ; \mathrm{CoSO}_{4} \cdot 7 \mathrm{H}_{2} \mathrm{O}$ $0.43 \mathrm{~g} \cdot \mathrm{dm}^{-3} ; \mathrm{FeCl}_{3} \cdot 6 \mathrm{H}_{2} \mathrm{O} 9.67 \mathrm{~g} \cdot \mathrm{dm}^{-3} ; \mathrm{H}_{3} \mathrm{BO}_{3} 0.03 \mathrm{~g} \cdot \mathrm{dm}^{-3} ; \mathrm{Na}_{2} \mathrm{MoO}_{4} \cdot 2 \mathrm{H}_{2} \mathrm{O} 0.024 \mathrm{~g} \cdot \mathrm{dm}^{-3}$. Sterilized by filtration on syringe filter.

Feed solution: glycerol $630 \mathrm{~g} \cdot \mathrm{dm}^{-3} ; \mathrm{MgSO}_{4} \cdot 7 \mathrm{H}_{2} \mathrm{O} 170 \mathrm{~g} \cdot \mathrm{dm}^{-3} ; \mathrm{NaH}_{2} \mathrm{PO}_{4} \cdot 2 \mathrm{H}_{2} \mathrm{O}$ $114.4 \mathrm{~g} \cdot \mathrm{dm}^{-3}$ (components sterilized separately).

Autoinduction media (expression of HPL): glycerol $5 \mathrm{~g} \cdot \mathrm{dm}^{-3}$; tryptone $8.4 \mathrm{~g} \cdot \mathrm{dm}^{-3}$; yeast extract $4.65 \mathrm{~g} \cdot \mathrm{dm}^{-3} ;\left(\mathrm{NH}_{4}\right)_{2} \mathrm{SO}_{4} 5.5 \mathrm{~g} \cdot \mathrm{dm}^{-3}$; glucose $0.25 \mathrm{~g} \cdot \mathrm{dm}^{-3}$; lactose $1 \mathrm{~g} \cdot \mathrm{dm}^{-3}$; $\mathrm{KH}_{2} \mathrm{PO}_{4} 0.136 \mathrm{~g} \cdot \mathrm{dm}^{-3} ; \mathrm{K}_{2} \mathrm{HPO}_{4} 0.174 \mathrm{~g} \cdot \mathrm{dm}^{-3} ; \mathrm{MgSO}_{4} \cdot 7 \mathrm{H}_{2} \mathrm{O} 0.246 \mathrm{~g} \cdot \mathrm{dm}^{-3}$ (sterilized separately); ampicillin $50 \mu \mathrm{g} \cdot \mathrm{cm}^{-3}$, sterilized by filtration.

\subsection{High Cell Density Cultivation of E. coli Expressing LOX}

The procedure described by Petrovičová [28] was used with minor modifications. Biomass was prepared in DASbox bioreactors $\left(350 \mathrm{~cm}^{3}\right.$, mini bioreaktor DASbox ${ }^{\circledR}$ system, Eppendorf, Germany) starting with $150 \mathrm{~cm}^{3}$ of SD media. Temperature was lowered to $18{ }^{\circ} \mathrm{C}$ after reaching $\mathrm{OD}_{600} \approx 50$ (exponential phase) and expression was induced with IPTG (final concentration $0.5 \mathrm{mM}$ ).

Enzyme activity was measured spectrophotometrically at $234 \mathrm{~nm}$ for the formation of conjugated double bonds using an extinction coefficient of $25,000 \mathrm{dm}^{3} \cdot \mathrm{mol}^{-1} \cdot \mathrm{cm}^{-1}$ [14].

\subsection{HPLC Analysis of Media}

Media were diluted $(\mathrm{R}=51)$ into mobile phase $\left(9 \mathrm{mM} \mathrm{H}_{2} \mathrm{SO}_{4}\right)$. Then, $20 \mu \mathrm{L}$ was injected and analyzed on a WATREX polymer IEX $\mathrm{H}^{+}$column (form $8 \mu \mathrm{m}, 250 \times 8 \mathrm{~mm}$ ) equipped with WATREX polymer IEX $\mathrm{H}^{+}$guard column (form $8 \mu \mathrm{m}, 40 \times 8 \mathrm{~mm}$ ) at $40{ }^{\circ} \mathrm{C}$. 
Signals were detected with RID (1260 Infinity (Agilent, Santa Clara, CA, USA), $40^{\circ} \mathrm{C}$ ) and UV detector $(258 \mathrm{~nm})$.

\subsection{Synthesis of 13-HPOT}

Synthesis was carried out in DASbox bioreactors $\left(350 \mathrm{~cm}^{3}\right.$, mini bioreactor DASbox ${ }^{\circledR}$ system, Eppendorf, Hamburg, Germany) with final volume of $60 \mathrm{~cm}^{3}, 200 \mathrm{rpm}$, and air flow of $3 \mathrm{sL} \cdot \mathrm{h}^{-1}$.

First, $444 \mathrm{mg}$ of dry cell weight of E. coli BL21(DE3) with expressed LOX was resuspended in chilled $\left(4{ }^{\circ} \mathrm{C}\right) 50 \mathrm{~cm}^{3} \mathrm{Na}$-borate buffer $(70 \mathrm{mM}, \mathrm{pH}=9)$ with Tween 20 $\left(0.06 \mathrm{~cm}^{3}\right)$. After $25 \mathrm{~min}$ of permeabilization, biotransformation was initiated by addition of $143 \mathrm{mg}(6 \mathrm{mM})$ or $286 \mathrm{mg}(12 \mathrm{mM})$ of $\alpha$-linolenic acid (70\% purity) resuspended in $5 \mathrm{~cm}^{3}$ of Na-borate buffer $(70 \mathrm{mM}, \mathrm{pH}=9)$, where $0.132 \mathrm{~mL}$ from the $\mathrm{NaOH}$ stock solution $\left(200 \mathrm{~g} \cdot \mathrm{dm}^{-3}\right)$ was added. This addition resulted in a decrease in the oxygen level to $0 \%$; after reaching $50 \%$ of dissolved oxygen (biotransformation finished), the reaction mixture was centrifuged $\left(4^{\circ} \mathrm{C}, 10,000 \times g, 15 \mathrm{~min}\right)$. Supernatant was transferred to an ice-cold bottle with a rubber plug and purged with $\mathrm{N}_{2}$ gas for 20 min while kept on ice. Then, it was dispensed into smaller volumes in an anaerobic atmosphere (anaerobic chamber Bactron, Sheldon Manufacturing, Cornelius, OR, USA), secured with parafilm, and stored at $-80{ }^{\circ} \mathrm{C}$ prior to use.

Concentration of hydroperoxides was determined by iodometric titration with $1 \mathrm{mM}$ $\mathrm{Na}_{2} \mathrm{~S}_{2} \mathrm{O}_{3}$, and quality was controlled by HPLC.

\subsection{Cultivation of E. coli Expressing HPL}

A single colony of E. coli JM109(DE3) with pET22b + hpl was taken from an LB agar plate and aseptically transferred into a sterile glass tube containing $3 \mathrm{~cm}^{3}$ of LB media with ampicillin $\left(50 \mu \mathrm{g} \cdot \mathrm{cm}^{-3}\right)$. The culture was incubated at $37^{\circ} \mathrm{C}, 200 \mathrm{rpm}$ (New Brunswick Scientific, Enfield, CT, USA) overnight (12-15 h). Then, $0.4 \mathrm{~cm}^{3}$ of the cell suspension was used to inoculate $40 \mathrm{~cm}^{3}$ of AI media with ampicillin $\left(50 \mu \mathrm{g} \cdot \mathrm{cm}^{-3}\right)$ in a $250 \mathrm{~cm}^{3}$ Erlenmeyer flask. The culture was incubated at $37^{\circ} \mathrm{C}, 200 \mathrm{rpm}$ for $2 \mathrm{~h}$ and then cooled to $20^{\circ} \mathrm{C}$ for $24 \mathrm{~h}$. This was considered to be the reference biomass. A second version of the induction was processed at $30{ }^{\circ} \mathrm{C}, 200 \mathrm{rpm}$ for $24 \mathrm{~h}$ [38]. Cells were harvested by centrifugation $(7197 \times g$, $15 \mathrm{~min}, 4^{\circ} \mathrm{C}$ ) and sediment was stored at $-20{ }^{\circ} \mathrm{C}$.

\subsection{Determination of HPL Activity}

The biotransformation was performed using a tabletop thermostat at $25^{\circ} \mathrm{C}, 900 \mathrm{rpm}$ with a final volume of $0.2 \mathrm{~cm}^{3}$ in $1.5 \mathrm{~cm}^{3}$ closable plastic tubes. Each tube was used as one measuring point and was triplicated. One unit of HPL activity was determined as the amount of enzyme that catalyzed the formation of $1 \mu \mathrm{mol}$ of C-6 aldehydes (cis-3-hexeal and trans-2-hexenal) per minute in the 5th minute of reaction (linear part of reaction) and was determined from the difference in concentration of C-6 aldehydes at 5th minute and at the beginning of reaction.

Biotransformation was initiated by addition of $68 \mu \mathrm{g}$ DCW of $E$. coli with expressed HPL in $0.02 \mathrm{~cm}^{3}$ of phosphate buffer $(0.1 \mathrm{M} ; \mathrm{pH}=8)$, which was added to $0.180 \mathrm{~cm}^{3}$ of hydroperoxide solution as described above (3.5). The reaction was stopped by addition of $0.002 \mathrm{~cm}^{3}$ of pure acetic acid and immediately extracted with $0.4 \mathrm{~cm}^{3}$ of ethyl acetate (containing $1 \mathrm{~g} \cdot \mathrm{cm}^{-3}$ of octanol as internal standard). The organic phase was analyzed by GC.

Negative control for LOX and HPL activity was performed with E. coli BL21(DE3) strains [28]. No LOX and HPL activity was determined (data not shown).

\subsection{GC Analysis of C-6 Aldehydes}

Aldehydes formed by catalytic activity of HPL were determined using a flame ionization detector (GC-FID; Agilent, Santa Clara, CA, USA) with an HP-FFAP capillary column (Agilent J\&W, $30 \mathrm{~m} \times 0.25 \mathrm{~mm} \times 0.25 \mu \mathrm{m}$, Agilent, Santa Clara, CA, USA) with $\mathrm{H}_{2}$ as the 
carrier gas $\left(1.5 \mathrm{~cm}^{3} \cdot \mathrm{min}^{-1}\right)$. The volume of injection was $1 \mu \mathrm{L}$, split 100:1. Oven temperature started at $70^{\circ} \mathrm{C}(6 \mathrm{~min})$, increasing to $200^{\circ} \mathrm{C}\left(30^{\circ} \mathrm{C} / \mathrm{min}\right)$, held for $3 \mathrm{~min}$, and finally increased to $230^{\circ} \mathrm{C}\left(30^{\circ} \mathrm{C} / \mathrm{min}\right)$ and held there for $5 \mathrm{~min}$.

The concentration of aldehydes was determined by comparison of their peak area to the peak area of the internal standard-octanol $1 \mathrm{~g} \cdot \mathrm{dm}^{-3}$.

\section{Conclusions}

Enzymes of the lipoxygenase pathway were successfully expressed: lipoxygenase (from Pseudomonas aeruginosa) in E. coli BL21 (DE3) by high cell density cultivation and hydroperoxide lyase (from Psidium guajava) in E. coli JM109(DE3) by autoinduction in flask cultivation. Whole-cell biocatalysts were applied for the synthesis of hydroperoxides and subsequently C-6 aldehydes in a cascade manner. HPL activity was increased 2.6-fold by the addition of $1 \mathrm{mM}$ of $\mathrm{Fe}^{\mathrm{II}+}$ to the culture media. Absolute activity produced was further increased 1.82-fold by increasing the cultivation temperature from 20 to $30^{\circ} \mathrm{C}$, which is an overall 13.94-fold increase compared to standard biomass (without addition).

HPL from plant sources is being used for the commercial production of GLVs [14] and considerable effort is being made to improve the yields of C-6 aldehydes [11]. Since cleavage of the fatty acid hydroperoxides is a production limiting step [10], the recombinant production of a large quantity of active enzyme on a cheap cultivation medium brings opportunities to overcome production drawbacks (fluctuation in plant material quality and price, low productivity). Moreover, the reported strategy for heme enzyme production is applicable for the production of different proteins-for example, for the production of human hemoglobin, which is limited by holoprotein formation in E. coli [39].

Author Contributions: Conceptualization, V.Š., M.R.; resources, M.R.; writing-original draft preparation, V.K. (Veronika Kazimírová); writing-review and editing, M.R.; supervision, M.R.; project administration, M.R., V.Š.; funding acquisition, M.R.; methodology, M.R., V.K. (Vladimír Krasňan); investigation, V.K. (Veronika Kazimírová), V.K. (Vladimír Krasňan), V.Z.; data curation, V.K. (Veronika Kazimírová), V.K. (Vladimír Krasňan). All authors have read and agreed to the published version of the manuscript.

Funding: This work was funded by the Agency for supporting research and development, according to Agreement Nr. APVV-18-0254. This article was written with the generous support of the Operational Program Integrated Infrastructure for the project: "Strategic research in the field of SMART monitoring, treatment and preventive protection against coronavirus (SARS-CoV-2)", Project no. 313011ASS8, co-financed by the European Regional Development Fund.

Data Availability Statement: The data presented in this study are available on request from the corresponding author.

Conflicts of Interest: The authors declare no conflict of interest.

\section{References}

1. Matsui, K. Green Leaf Volatiles: Hydroperoxide Lyase Pathway of Oxylipin Metabolism. Curr. Opin. Plant Biol. 2006, 9, 274-280. [CrossRef]

2. ul Hassan, M.N.; Zainal, Z.; Ismail, I. Green Leaf Volatiles: Biosynthesis, Biological Functions and Their Applications in Biotechnology. Plant. Biotechnol. J. 2015, 13, 727-739. [CrossRef]

3. Mukhtarova, L.S.; Mukhitova, F.K.; Gogolev, Y.V.; Grechkin, A.N. Hydroperoxide Lyase Cascade in Pea Seedlings: Non-Volatile Oxylipins and Their Age and Stress Dependent Alterations. Phytochemistry 2011, 72, 356-364. [CrossRef] [PubMed]

4. Zhao, Y.; Xu, S.; Lu, H.; Zhang, D.; Liu, F.; Lin, J.; Zhou, C.; Mu, W. Effects of the Plant Volatile Trans-2-Hexenal on the Dispersal Ability, Nutrient Metabolism and Enzymatic Activities of Bursaphelenchus Xylophilus. Pestic. Biochem. Physiol. 2017, 143, 147-153. [CrossRef] [PubMed]

5. Mu, W.; Xue, Q.; Jiang, B.; Hua, Y. Molecular Cloning, Expression, and Enzymatic Characterization of Solanum Tuberosum Hydroperoxide Lyase. Eur. Food Res. Technol. 2012, 234, 723-731. [CrossRef]

6. Feussner, I.; Wasternack, C. The Lipoxygenase Pathway. Annu. Rev. Plant. Biol. 2002, 53, 275-297. [CrossRef] [PubMed]

7. Villaverde, J.J.; van der Vlist, V.; Santos, S.A.O.; Haarmann, T.; Langfelder, K.; Pirttimaa, M.; Nyyssölä, A.; Jylhä, S.; Tamminen, T.; Kruus, K.; et al. Hydroperoxide Production from Linoleic Acid by Heterologous Gaeumannomyces Graminis Tritici Lipoxygenase: Optimization and Scale-Up. Chem. Eng. J. 2013, 217, 82-90. [CrossRef] 
8. RoyChowdhury, M.; Li, X.; Qi, H.; Li, W.; Sun, J.; Huang, C.; Wu, D. Functional Characterization of 9-/13-LOXs in Rice and Silencing Their Expressions to Improve Grain Qualities. BioMed Res. Int. 2016, 2016, 4275904. [CrossRef] [PubMed]

9. Shaaban, H.A.; Mahmoud, K.F.; Amin, A.A.; El Banna, H.A. Application of Biotechnology to the Production of Natural Flavor and Fragrance Chemicals. Res. J. Pharm. Biol. Chem. Sci. 2016, 7, 2670-2717.

10. Brühlmann, F.; Bosijokovic, B.; Ullmann, C.; Auffray, P.; Fourage, L.; Wahler, D. Directed Evolution of a 13-Hydroperoxide Lyase (CYP74B) for Improved Process Performance. J. Biotechnol. 2013, 163, 339-345. [CrossRef]

11. Liu, Q.; Hua, Y. Continuous Synthesis of Hexanal by Immobilized Hydroperoxide Lyase in Packed-Bed Reactor. Bioprocess. Biosyst. Eng. 2015, 38, 2439-2449. [CrossRef]

12. Contreras, C.; Beaudry, R. Lipoxygenase-Associated Apple Volatiles and Their Relationship with Aroma Perception during Ripening. Postharvest Biol. Technol. 2013, 82, 28-38. [CrossRef]

13. Vong, W.C.; Liu, S.-Q. Bioconversion of Green Volatiles in Okara (Soybean residue) into Esters by Coupling Enzyme Catalysis and Yeast (Lindnera saturnus) Fermentation. Appl. Microbiol. Biotechnol. 2018, 102, 10017-10026. [CrossRef]

14. Liu, Q.; Kong, X.; Zhang, C.; Chen, Y.; Hua, Y. Immobilisation of a Hydroperoxide Lyase and Comparative Enzymological Studies of the Immobilised Enzyme with Membrane-Bound Enzyme. J. Sci. Food Agric. 2013, 93, 1953-1959. [CrossRef] [PubMed]

15. Lu, J.; Zhang, C.; Leong, H.Y.; Show, P.L.; Lu, F.; Lu, Z. Overproduction of Lipoxygenase from Pseudomonas aeruginosa in Escherichia coli by Auto-Induction Expression and Its Application in Triphenylmethane Dyes Degradation. J. Biosci. Bioeng. 2020, 129, 327-332. [CrossRef]

16. Kelle, S.; Zelena, K.; Krings, U.; Linke, D.; Berger, R.G. Expression of Soluble Recombinant Lipoxygenase from Pleurotus Sapidus in Pichia Pastoris. Protein Expr. Purif. 2014, 95, 233-239. [CrossRef] [PubMed]

17. Zhang, C.; Tao, T.; Ying, Q.; Zhang, D.; Lu, F.; Bie, X.; Lu, Z. Extracellular Production of Lipoxygenase from Anabaena sp. PCC 7120 in Bacillus Subtilis and Its Effect on Wheat Protein. Appl. Microbiol. Biotechnol. 2012, 94, 949-958. [CrossRef]

18. Mukhtarova, L.S.; Brühlmann, F.; Hamberg, M.; Khairutdinov, B.I.; Grechkin, A.N. Plant Hydroperoxide-Cleaving Enzymes (CYP74 Family) Function as Hemiacetal Synthases: Structural Proof of Hemiacetals by NMR Spectroscopy. Biochim. Biophys. Acta BBA-Mol. Cell Biol. Lipids 2018, 1863, 1316-1322. [CrossRef] [PubMed]

19. Rehbock, B.; Berger, R. Covalent Immobilization of a Hydroperoxidase Lyase from Mung Beans (Phaseolus radiatus L.). Biotechnol. Tech. 1998, 12, 539-544. [CrossRef]

20. Atwal, A.S.; Bisakowski, B.; Richard, S.; Robert, N.; Lee, B. Cloning and Secretion of Tomato Hydroperoxide Lyase in Pichia Pastoris. Process. Biochem. 2005, 40, 95-102. [CrossRef]

21. Santiago-Gómez, M.P.; Vergely, C.; Policar, C.; Nicaud, J.-M.; Belin, J.-M.; Rochette, L.; Husson, F. Characterization of Purified Green Bell Pepper Hydroperoxide Lyase Expressed by Yarrowia Lipolytica: Radicals Detection during Catalysis. Enzyme Microb. Technol. 2007, 41, 13-18. [CrossRef]

22. Ge, B.; Chen, Y.; Yu, Q.; Lin, X.; Li, J.; Qin, S. Regulation of the Heme Biosynthetic Pathway for Combinational Biosynthesis of Phycocyanobilin in Escherichia coli. Process. Biochem. 2018, 71, 23-30. [CrossRef]

23. Varnado, C. Enhancing Expression of Recombinant Hemoproteins: Progress toward Understanding Structure/Function and Therapeutic Application. Ph.D. Thesis, Auburn University, Auburn, AL, USA, 2006.

24. Sudhamsu, J.; Kabir, M.; Airola, M.V.; Patel, B.A.; Yeh, S.-R.; Rousseau, D.L.; Crane, B.R. Co-Expression of Ferrochelatase Allows for Complete Heme Incorporation into Recombinant Proteins Produced in E. coli. Protein Expr. Purif. 2010, 73, 78-82. [CrossRef]

25. Delcarte, J.; Fauconnier, M.-L.; Jacques, P.; Matsui, K.; Thonart, P.; Marlier, M. Optimisation of Expression and Immobilized Metal Ion Affinity Chromatographic Purification of Recombinant (His)6-Tagged Cytochrome P450 Hydroperoxide Lyase in Escherichia coli. J. Chromatogr. B 2003, 786, 229-236. [CrossRef]

26. Woyski, D.; Cupp-Vickery, J.R. Enhanced Expression of Cytochrome P450s from Lac-Based Plasmids Using Lactose as the Inducer. Arch. Biochem. Biophys. 2001, 388, 276-280. [CrossRef] [PubMed]

27. Tijet, N.; Wäspi, U.; Gaskin, D.J.; Hunziker, P.; Muller, B.L.; Vulfson, E.N.; Slusarenko, A.; Brash, A.R.; Whitehead, I.M. Purification, Molecular Cloning, and Expression of the Gene Encoding Fatty Acid 13-Hydroperoxide Lyase from Guava Fruit (Psidium guajava). Lipids 2000, 35, 709-720. [CrossRef] [PubMed]

28. Petrovičová, T.; Gyuranová, D.; Plž, M.; Myrtollari, K.; Smonou, I.; Rebroš, M. Application of Robust Ketoreductase from Hansenula Polymorpha for the Reduction of Carbonyl Compounds. Mol. Catal. 2021, 502, 111364. [CrossRef]

29. Vick, B.A. A Spectrophotometric Assay for Hydroperoxide Lyase. Lipids 1991, 26, 315-320. [CrossRef]

30. de Carvalho, C.C.C.R. Whole Cell Biocatalysts: Essential Workers from Nature to the Industry. Microb. Biotechnol. 2017, 10, 250-263. [CrossRef]

31. Noordermeer, M.A.; van der Goot, W.; van Kooij, A.J.; Veldsink, J.W.; Veldink, G.A.; Vliegenthart, J.F.G. Development of a Biocatalytic Process for the Production of C6-Aldehydes from Vegetable Oils by Soybean Lipoxygenase and Recombinant Hydroperoxide Lyase. J. Agric. Food Chem. 2002, 50, 4270-4274. [CrossRef] [PubMed]

32. Jacopini, S.; Vincenti, S.; Mariani, M.; Brunini-Bronzini de Caraffa, V.; Gambotti, C.; Desjobert, J.-M.; Muselli, A.; Costa, J.; Tomi, F.; Berti, L.; et al. Activation and Stabilization of Olive Recombinant 13-Hydroperoxide Lyase Using Selected Additives. Appl. Biochem. Biotechnol. 2017, 182, 1000-1013. [CrossRef]

33. Chu, D.; Barnes, D.J. The Lag-Phase during Diauxic Growth Is a Trade-off between Fast Adaptation and High Growth Rate. Sci. Rep. 2016, 6, 25191. [CrossRef] 
34. Mayer, S.; Junne, S.; Ukkonen, K.; Glazyrina, J.; Glauche, F.; Neubauer, P.; Vasala, A. Lactose Autoinduction with Enzymatic Glucose Release: Characterization of the Cultivation System in Bioreactor. Protein Expr. Purif. 2014, 94, 67-72. [CrossRef]

35. Ukkonen, K.; Mayer, S.; Vasala, A.; Neubauer, P. Use of Slow Glucose Feeding as Supporting Carbon Source in Lactose Autoinduction Medium Improves the Robustness of Protein Expression at Different Aeration Conditions. Protein Expr. Purif. 2013, 91, 147-154. [CrossRef] [PubMed]

36. Kabbua, T.; Anwised, P.; Boonmee, A.; Subedi, B.P.; Pierce, B.S.; Thammasirirak, S. Autoinduction, Purification, and Characterization of Soluble $\alpha$-Globin Chains of Crocodile (Crocodylus siamensis) Hemoglobin in Escherichia coli. Protein Expr. Purif. 2014, 103, 56-63. [CrossRef] [PubMed]

37. Stover, C.K.; Pham, X.Q.; Erwin, A.L.; Mizoguchi, S.D.; Warrener, P.; Hickey, M.J.; Brinkman, F.S.; Hufnagle, W.O.; Kowalik, D.J.; Lagrou, M.; et al. Complete Genome Sequence of Pseudomonas aeruginosa PAO1, an Opportunistic Pathogen. Nature 2000, 406, 959-964. [CrossRef] [PubMed]

38. Studier, F.W. Protein Production by Auto-Induction in High-Density Shaking Cultures. Protein Expr. Purif. 2005, 41, 207-234. [CrossRef] [PubMed]

39. Graves, P.E.; Henderson, D.P.; Horstman, M.J.; Solomon, B.J.; Olson, J.S. Enhancing Stability and Expression of Recombinant Human Hemoglobin in E. coli: Progress in the Development of a Recombinant HBOC Source. Biochim. Biophys. Acta BBA—Proteins Proteom. 2008, 1784, 1471-1479. [CrossRef] 